\title{
Khoi en Oosgrensafrikaans
}

Oompies Kedoompie het in 'n val geloop Oompies Kedoompie was toe mooitjies genoop om stukstuk uit die Kaap uit weg te loop ...

\section{MCJ van Rensburg}

Navorsingsgenoot: Navorsingseenheid Tale en literatuur in die SA konteks, Noordwes-Universiteit, Potchefstroom-kampus, Suid-Afrika

E-pos: cvrensb@mweb.co.za

\section{Opsomming}

Den Besten se studies oor die invloed van Khoi op Afrikaans, oor 'n tydperk van 25 jaar, het 'n impetus gegee vir opvolgondersoeke oor temas waarvan hy in sy werk aanduidings gegee het. In hierdie studie word daar, in aansluiting by sy werk, aandag gegee aan twee fases van die Khoi-Khoi se nuwe aanleerderstaal, Afrikaans, voor en na die begin van die agtiende eeu. Voor die begin van die agtiende eeu was daar heelwat faktore wat die vordering van die KhoiKhoin se aanleerderstaal bemoeilik het. Daarna het die aanleerderstaal 'n ander rol in die Binneland gespeel, in die gebied wat naastenby tussen die Hottentots-Hollandberge en GraaffReinet lê. Saam met die taal van die veeboere, was dit die hooftaal in daardie gebied. Die tale het mekaar vir bykans 'n eeu lank oor en weer beïnvloed, voordat dit met die Groot Trekbeweging noordwaarts geneem is.

Sleutelwoorde: Khoi-Khoin, oosgrenstaalgebied, skeepsvaart, taalkontak, taalverplasing, VOC, wording van Afrikaans

\section{Khoi and Eastern border Afrikaans}

\begin{abstract}
Den Besten studied the influence of Khoi on Afrikaans for a period of 25 years, which gave an impetus for research in the same vein. In this study attention is given to two phases of the learner variety of the Khoi-Khoin, before and after the beginning of the eighteenth century, following some indications in his work. The development of the learner variety of the KhoiKhoin was hampered in various ways before the beginning of the eighteenth century. The situation changed considerably thereafter, when this variety became one of the two main languages, next to the language of the cattle farmers, in the interior, approximately between
\end{abstract}


the Hottentot-Holland mountains and Graaff-Reinet. The language that resulted from the outcome of the influence of these languages on each other, for nearly a century, was taken to the north with the Great Trek migration.

Keywords: Eastern border language area, genesis of Afrikaans, Khoi-Khoin, language contact, language displacement, language loss, maritime trade, VOC

\section{Inleiding}

\subsection{Aanloop}

Daar is van vroeg af al daarop gewys dat Afrikaans onbetwisbare Khoi-invloed toon. ${ }^{1}$ Hans den Besten se indringende studies (veral Den Besten 1978, 1985, 1986, 1987a, 1989 en 1994) oor hierdie onderwerp, waarna verderaan verwys sal word, maak deel van sy nalatenskap uit.

Die tekens van Khoi in Afrikaans lê soms verskuil, ander kere maak dit weer deel van die taaloppervlakte uit. Die naam Hooge Kraal, by George in die Suid-Kaap, is interessant genoeg, volgens Nienaber (1989:XXV; 410 e.v.), 'n Nederlandse vertaling van die Goringhaikwa stamnaam van wie Van Riebeeck meermale in sy dagboek skryf (Nienaber 1989:410 e.v.). Soos wat dit met ander Khoi-Khoin-stamme ook die geval was, het die Goringhaikwa voor die einde van die sewentiende eeu uit die Wes-Kaap weggetrek. Vir amper 'n eeu lank het ondersoekers verniet na spore van hierdie naam en hierdie mense gesoek. Reisigers kan streke deurreis maar die mense teen die agtergrond mis. Die skrywers van dagregisters se verhale raak ook vergete, hoewel plekname en eiename, daarenteen, aanhou stories vertel en die stukkies van 'n legkaart vorm wat op die een of ander tyd weer aanmekaar gesit kan word.

Die woord Goringhaikwa kan opgebreek word in drie betekenisdraende dele, wat meer foneties soos volg geskryf kan word: [!kuri]-; [//-ais]- en -[kwa]. Die laaste lid $(+\mathrm{ml}+\mathrm{mv})$ word in Afrikaans weergegee met -hulle (soos in Pa-hulle/Pa-goed, wat die betekenis van mense ook insluit). Die voorlaaste lid beteken kraal, of meer abstrak, stam. Die eerste lid beteken hoog, en in 'n abstrakte sin trots. Om die betekenis van hierdie naam in 'n aanleerderstaal aan anderstalige koloniste te verduidelik: Hoëkraalmense. Onder mekaar beteken die naam egter Trotse stam se mense ((Nienaber 1963:309); Nienaber (1989:418 e.v. 639 e.v.)).

Die Goringhaikwa (trotse volk se mense) het met hulle trek uit die Wes-Kaap waarskynlik in twee verdeel. Een deel het vanaf ongeveer 1680 Weskus-langs weggetrek en in die Oranjerivieromgewing gaan woon. Die ander groep, wat hier ter sprake is, het ooswaarts getrek, en teen die einde van die sewentiende eeu in die omgewing van die teenswoordige George gaan woon. (Ten minste nog 'n plek, naby Heroldsbaai, was ook as Hoge Kraal bekend. 'n Rivier, ook in die omgewing, is Hogekraalrivier genoem (Nienaber 1989:XXV).

\footnotetext{
${ }^{1}$ Traill wys daarop dat Khoi nie sommer spoorloos verdwyn het nie. Khoi, skryf hy, "has also exerted an influence on the development of Afrikaans and has extensively restructured the phonological systems of Xhosa and Zulu, greatly enriching the lexicons of those two languages in the process (Traill 1995:3).
} 
Een van die name wat Van Riebeeck vir die Gorinhaikwa gebruik het, is "Caepmans", ${ }^{2}$ omdat hulle met sy aankoms in "die Kaapse Skiereiland tot aan Kaappunt gewoon het, die oorspronklike 'Kaap die Goeie Hoop" (Nienaber 1989:409). (Van Riebeeck se benaming "Caepmans" kon waarskynlik ook die Strandlopers (Goringhaiconas) ingesluit het (cit loc:409).) Toe grond aan die eerste vryburgerboere toegeken is, is dit presies "die Goringhaikwas se tradisionele grondgebied waar die indringing plaasvind [...] die gebied waar die Goringhaikwas nog woon- en weidingsregte laat geld het," sê Nienaber (1989:416). (Vgl. ook Giliomee 200:8. behou 2009) Van Riebeeck-hulle het nie veel belangstelling in die Goringhaikwa getoon nie. Hulle het te min vee besit, maar kon darem op ongeveer 300 vegters staatmaak. Saam met die Gorachoukwa (mense van kaptein Gora), wat 700 weerbare man gehad het, het hulle 'n alliansie gevorm wat van 19 Mei 1659 af in 'n elfmaandelange oorlog teen die Hollanders betrokke geraak het (Schoeman 2001:85 e.v.). Ander groepe het "simpatieke betrokkenheid" met die mede-Khoi-Khoin getoon (Nienaber 1989:39) wat op 'n wyer ongelukkigheid dui met die Wes-Kaap as woonplek, en die omstandighede daar. Van Khoi-Khoin kant af was daar egter ook tydens hierdie oorlog aktiewe ondersteuning (deur Oedasoa van die Saldanhars) vir die Hollanders (Nienaber 1989:417). Die Khoi-Khoin wat steeds oor baie sake ontevrede was, het verkies om die Wes-Kaap te begin verlaat. Nienaber skryf dat met die wegtrek van die Khoi-Khoin uit die Wes-Kaap, die Gorachoukwa (mense van kaptein Gora), die vennote van die Goringhaikwa tydens die eerste oorlog, "onder die heel eerstes (was) om pad te gee" (Nienaber 1989:16).

Nienaber (1989: 413) verwys in sy bespreking van die Khoi stamnaam Goringhaikwa (vgl. hierbo) na gegewens van Engelbrecht oor die persoonseienaam Koeries wat toe (1936) in Pacaltsdorp (die vroeëre Hoge Kraal (Raper 1989:298; Nienaber 1989:XXV) voorgekom het. Koeries hou verband met die Goring-gedeelte [!kuri-] van die genoemde stamnaam, en [//ais] = stam/volk, in latere optekeninge van die stamnaam as Goringeis (Nienaber 1989:418). Navraag (by ' $n$ ou ingesetene van Stilbaai) toon aan dat hierdie persoonseienaam tans (2011) nog steeds in daardie omgewing bekend is. As lid van die Trotse stam se mense, dra die naam Koeries, al is dit onwetend, vandag nog die betekenis trotse mens.

Hoge Kraal, soos talle ander plekname in Suid-Afrika, herinner aan formele Nederlands. Die “ontwikkelde Kaapse burger," sê Scholtz (volgens Raidt $1976^{2}: 203$ ) kon Nederlands sowel as (die latere) Afrikaans gebruik. Intrekkers in die Hoge Kraal-gebied, ook uit die WesKaap, het die Nederlandse skyn bewaar, en formele Nederlands vir plekname gebruik. Hulle spreektaal was egter nie Nederlands nie.

\subsection{Doelwitte}

Die bostaande verhaal (1.1) gee 'n opsomming van die rol van die Khoi-Khoin in die WesKaap vir die eerste 50 jaar nadat die Vereenigde Oos-Indiese Kompanjie (VOC) die halfwegstasie aan die Kaap begin het, en hulle lotgevalle daarna. In hierdie hoofstuk word aangevoer dat die omstandighede vir Khoi-invloed op Afrikaans in die binneland, tussen 1700 en 1840, baie gunstiger was as in die voorafgaande 50 jaar tydperk in die Wes-Kaap, en skets die besonderhede waarvolgens dit moontlik was. In die binneland kon Khoi-Khoin vroeë

\footnotetext{
${ }^{2}$ Eva Krotoa, wat in Van Riebeeck se huishouding tuis was, en as tolk opgetree het, was 'n familielid van die Kaapmans (Nienaber 1989:19).
} 
invloede uit ander tale, in hulle aanleerderstaal, makliker oordra, en kon Khoi-spore makliker op ander tale agterlaat word.

\subsection{Die Kaapse taalsituasie}

Aan die vroeë Kaap, 'n paar dekades na 1652, is daar tot soveel as 'n tiental tale gepraat (Ponelis 1993:3 e.v.). Dit het oor en weer taalbeïnvloeding baie moontlik gemaak. Die latere Afrikaans, sê Ponelis (1993:27), "has been affected profoundly by language contact, which induced borrowing and interlectal restructuring (creolisation) owing to secondary proficiency." Nie een van hierdie tale kon egter langdurige invloed op 'n ander een uitoefen nie. So 'n moontlikheid is geïnhibeer deur die oorheersing van die taal van duisende matrose en soldate van die verbygaande vlote, wat nie almal Nederlands goed magtig was nie, en wat vir periodes van sowat drie weke, twee keer of meer per jaar, aan die Kaap vertoef het. (Vgl. De Ruyter en Kotze (2002) se uiteensetting van die invloed van hierdie besoekers op die Kaapse taalsituasie.) Die Kompanjie het 'n web van Nederlandse taalidentiteit oor al sy besittings gespin, alhoewel Nederlands verreweg nie die moedertaal van die meeste van sy werknemers was nie. Aan die Kaap is Nederlands as die erkende taal voorgehou.

Die vryburgerboere het teen die begin van die agtiende eeu die binneland begin intrek, 'n gebied tussen die Hottentots-Hollandberge en die berge ten noorde daarvan, tot ooswaarts aan die Xhosa-gebiede, noord-wes van Graaff-Reinet, en die gebied na sowat sewentig jaar beset. Giliomee (2009:28) onderskei daarna drie streke in die Kaap: die Kaapstadomgewing, die plattelandse Kaap, en die grensgebied oos van die Hottentots-Hollandberge. Historici is dit eens dat die oorsteek van die berge'n belangrike hoofstuk in die Kaapse geskiedenis ingelui het.

Teen dieselfde tyd het die Khoi-Khoin wat uit die Wes-Kaap weggetrek het, hulle ook in die binneland gevestig, hoofsaaklik in dieselfde gebied. Ander Khoi-Khoinstamme was toe alreeds daar woonagtig.

Belangrike hoofstukke in die geskiedenis van die tale van hierdie twee groepe is daar geskryf. Vir die Khoi is 'n proses voltrek wat alreeds onderweg was. "... [W]ithin a hundred years of 1652, the western Cape Khoe language had begin to disappear, being gradually replaced by Khoe-Dutch, and the eastern Khoe varieties had been absorbed by Xhosa ...", skryf Traill (1995:3). Die ander taal, die taal wat die vryburgerboere gepraat het, het gedurende hierdie tydperk sy besondere beslag gekry, en word hier Oosgrensafrikaans ${ }^{3}$ genoem, en die binnelandse streek waar dit gepraat is, die oosgrenstaalgebied/oosgrensgebied.

\footnotetext{
3 (i) Die naam Oosgrensafrikaans, vir die vorms van Afrikaans wat in hierdie gebied gepraat is, is deur Van Rensburg (1983:141) gebruik, asook in daaropvolgende publikasies oor hierdie onderwerp. Die vroeë sogenaamde vrye boere onder die Kompanjie, wat begin by die vryburgers, en wat dikwels onder haglike omstandighede moes oorleef, het 'n lang geskiedenis van verset teen grense. Daaronder val byvoorbeeld, vroeg al, verset teen Van Riebeeck in 1668, teen die VOC-amptenare in 1705-1707, in Swellendam in 1795, by Slagtersnek in 1813 en met die Patriotbeweging van 1778-1787 se eis vir groter verteenwoordiging in Kaapse bestuursake (Giliomee 1979:338-358). Die verset kulmineer met die Groot Trek in 1830. Verset teen grense het ook versit van grense meegebring. Daar is probeer om hierdie fasette in die naam Oosgrensafrikaans te vervat. Ander ondersoekers (Ponelis 1993:56) gebruik die term Oostelike Afrikaans vir hierdie variëteit. Die kaart van die besetting van die oosgrensgebied wat hier afgedruk is, kom ooreen met kaarte van o.a. Bergh en Visagie (1985:15), Giliomee en Mbenga (2007:62), Ponelis (1993:VI) en Van Rensburg (1991). (ii) Die term Oosgrensafrikaans sluit ook aan by Elphic en Malherbe $1989^{2}: 8$, wat 'n grensgebied beskryf as 'n streek waar
} 


\subsection{Aansluiting}

Den Besten (1994:6 $\left.{ }^{4}\right)$ het hom soos volg uitgelaat oor die problematiek wat hier aangeroer word:

When the tribal Khoekhoen retreated into the interior (1713) the basis of their linguistic influence had already been laid. However Dutch colonists who headed north and east in the 18th century again entered Khoekhoe area. The same applies to runaway slaves and servants and to slaves and servants accompanying the colonists. The colonists, servants and slaves brought their own linguistic influences to the north and to the east. ... But at the same time the colonists, servants and slaves from the West Cape came under the renewed linguistic influence of the Khoekhoen.

Nienaber (1942:XV) wys ook op die belang van die binnelandse tydperk in die vorming van Afrikaans, en sê dat dit "heel natuurlik is om al die voorbeelde van Afrikaans in die periferie te vind."

\section{Khoi-Khoin en Nederlands voor 1700 in die Wes-Kaap}

\subsection{Beperkte Nederlandsvaardigheid}

Taalkontak met die Khoi-Khoin in die Wes-Kaap het van die begin af Nederlands bevoordeel ten koste van Khoi, sê Steyn (1980:106). Verder wys hy uit dat dit die Khoi-Khoin is wat gedeeltelik tweetalig was, en daarom blootgestel was aan taalverplasing (Steyn 1980:107).

Die Nederlanders het hulle blind gestaar teen die vreemdheid van Khoi, en het dit as onaanleerbaar beskou. In die taalkontaksituasies tussen die Khoi-Khoin en die nedersetters was die Khoi-Khoin die aanleerders, en hulle het die nedersetters se taal nagemaak en probeer praat, sterk beïnvloed deur hulle moedertaal in die beginstadium van 'n kommunikasiesituasie waar klanknabootsing en gebare ook 'n rol gespeel het. Wanneer wedersydse blootstelling dit toelaat, en die aanleerderstaal beter beheer is, het die koloniste hulle taal by die kontaksituasie aangepas en die Khoi-vorm wat hulle gehoor het, teruggepraat (Den Besten 1995:7-8). Die Khoi-Khoin, as meertaliges, het ook hulle aanleerderstaal aan die nedersetters geleer (Nienaber 1964:199), soos wat die pleknaam Leeu-Gamka (Leeu-Leeu) aandui. Hoe die wedersydse beïnvloeding ook al verloop het, "Khoekhoen and their language were of primary importance for the genesis of Afrikaans ...” (Den Besten 1994:2).

Tydens die eerste helfte van die Nederlandse besetting van die Kaap toon waarnemings en dokumente dat die Aanleerdersnederlands van die Khoi-Khoin nie ver gevorder het in die rigting van Nederlands nie. Van Rheede sê in 1685 "the Khoi speak Dutch '... in their way brokenly and almost unintelligibly," volgens Ponelis (1993:11) se samevatting van Van Rheede se moeilik verstaanbare opmerking daaroor. Burchell (1810-1815) het na 'n tog in die binneland berig oor die "corrupt dialect of the Hottentots" (Raidt 1976:152). Die

gereelde kontak plaasvind tussen groepe wat kultureel van mekaar verskil, en waar ten minste een van die groepe die ander probeer beheer, maar nie heeltemal daarin slaag nie. (iii) Afrikaans word sover moontlik net gebruik om na gestandaardiseerde Afrikaans te verwys. In aanhalings en by verwysings kan hierdie uitgangspunt nie altyd gevolg word nie. Bladsynommers en aanhalings volgens die manuskrip. 
omstandighede aan die Wes-Kaap van die eerste 50 jaar was om verskeie redes nie ideaal vir grootskaalse verwerwing van Nederlands deur die Khoi-Khoin nie, en daarom ook nie vir wedersydse taalbeïnvloeding nie. Wedersydse beïnvloeding hou natuurlik nie net in dat die Khoi-Khoin die taalbeheer oor hulle aanleerderstaal kon opknap nie, maar ook dat hulle aanleerdersvariëteit - die "Khoekhoe Dutch" wat Den Besten dikwels te berde gebring het (o.a. Den Besten 1994:6) - op sy beurt weer invloed op Kaapse Nederlands en Vryburgernederlands kon uitoefen. Eva het Nederlands onder gunstige omstandighede beter onder die knie kon kry, maar haar geval kan nie veralgemeen word nie.

Voorbeelde van die heel vroeë pidgin/kreoolse-tipe aanleerdersvorm wat Khoi-sprekers gebruik het, moontlik tot so teen 1670-1680 (of selfs vroeër), is in min bronne opgeteken. Ponelis (1993:27) verklaar waarom nie meer van hierdie vroeë aanleerdersvorme behoue gebly het nie, wat behoort te gebeur het as hierdie soort taalgebruik wyer uitgekring het: "The continued presence of spoken Dutch inhibited creolisation due to secondary proficiency and the use of Dutch as a transactional language." Een van die voorbeelde is deur Ten Rhyne in 1671 opgeteken, een van 1672 kom uit die Kaapse argief, en Kolbe het 10 opgeteken (Nienaber 1934:17-18); (Ponelis 1993:30-31; Raidt 1976:111-112). Kolbe was tussen 1705 en 1713 aan die Kaap, maar omrede die korrelasie met die ander data, moes sy voorbeelde vroeër opgeskryf gewees het. Ander opgetekende taalgegewens uit vroeg 1700 lyk anders as hierdie vroeë voorbeelde uit die 1670's. Klanknabootsing in die vroeë data, soos boeba, val op (vgl. ook Nienaber 1994:149; Den Besten 1889, oor boeba en soortgelyke voorbeelde). In die Ten Rhynesinnetjie, uit 1671, kom boeba byvoorbeeld voor: Die man my soon witte boeba geme (Die man sal my mooi wit beeste gee). By die Kolbe-sinnetjie: Gy dit Beest fangum zoo (Jy vang die dier só), speel handgebare weer 'n rol. Soortgelyke uitings kon heelwaarskynlik lank voor 1671 al by die Khoi-Khoin-aanleerders van Nederlands gehoor word. Die aanleerders se moedertaalinvloed speel ook 'n rol, soos wat die opvallende -um na konsonante (fangum) betref, wat Den Besten (1987:35 e.v.) toeskryf aan die invloed van 'n Khoi nominale uitgang. In hierdie data kom, ewe opvallend, ons drie keer in onderwerpsposisie voor (vgl. Nederlands wij), byvoorbeeld ons denkum (by Kolbe). Dit lyk met die eerste oogopslag asof ons in die onderwerpsposisie, soos dit in hedendaagse Afrikaans voorkom, binne die eerste 50 jaar na die VOC-besetting 'n deel van Afrikaans geword het. (Vgl. ook 5.2.)

\section{Enkele redes vir swak kennis van Nederlands deur die Khoi-Khoin, voor 1700}

\subsection{Kort taalkontaktyd en min deelnemers}

Die eerste Khoi-Nederlandse tekste (waarvan hierbo melding gemaak is) gee 'n aanduiding van taalverwerwing wat nie sy natuurlike verdere verloop kon neem nie. Meer kontak, en 'n langer blootstelling, sal 'n resultaat oplewer wat baie meer na Nederlands lyk as die tekste uit bogenoemde drie bronne. Taalkontak moet lank genoeg duur voordat daar 'n beduidende wedersydse invloed uitgewys kan word. Scholtz (1980:37) skryf byvoorbeeld die gebrek aan Franse invloed in die Kaap daaraan toe dat Frans "te kort 'n lewenskragtige bestaan gehad" het.

Die Khoi-Khoin is in die sewentiende eeu nie by die Nederlandse kulturele netwerk betrek nie (Ponelis 1993:13). Dit beteken dat daar nie stimulasie van Nederlandse kant af was vir die skep van taalkontaksituasies nie. Binne gesinsverband, en deur verhoudings, kan taalkontak 
oor langer periodes moontlik bevorder word. Dit het ook nie gebeur nie. Aan die Kaap is daar net een huwelik tussen 'n Nederlander en 'n Khoi-Khoin-vrou voltrek (Pieter van Meerhoff en Eva Krotoa). Enkellopende mans het voorkeur gegee aan vrouens uit Bengale, Indonesiërs en vryswartes (Ponelis 1993:7). Eers teen die einde van die sewentiende eeu was intensiewer kontak, en meer blywend van aard, tussen die vryburgerboere en Khoi-Khoin op die plase in die buitewyke moontlik. Die getalle was egter beperk, aangesien daar teen daardie tyd nog relatief min vryburgerboere en min Khoi-Khoin-plaaswerkers was. Scholtz (1980:38) noem hierdie kontak "sporadies". In die beginjare was 'n klein persentasie van die vryburgers boere; later sou die verhouding verander. Volgens Elphick en Giliomee $\left(1989^{2}: 524\right)$ was daar 125 vryburgers in 1670, en tussen 1657 en 1706, 1613 vryburgers (Giliomee 2009) in die Kaap. 'n Gedeelte van hulle, die derde wat boere was (sowat 540), en hulle knegte (sowat 400), sou aan hierdie taalkontaksituasie kon deelgeneem het, en hulle taal sou ook beïnvloeding deur die Khoi gereflekteer het.

\subsection{Nederlandse taalvoorbeeld}

Die soldate en matrose van die verbygaande vlote het die sprekers van watter een van die talle tale aan die Kaap ten minste twee of meer kere jaarliks met hulle Seevaartnederlands oorspoel. Gesien die rigiede sosiale struktuur aan die Kaap, was die kontakmoontlikhede tussen hulle en die Khoi-Khoin beter as tussen die Khoi-Khoin en die Kompanjieamptenare. Die matrose en soldate se taalvoorbeeld, en kontak met die sprekers, het nie 'n stabiele doelwit vir aanleerders gestel nie. Die teikentaal het saam met die vlote bly wissel.

\subsection{Onvoldoende taalkontakgeleenthede}

'n Groot persentasie van die kontak tussen die Khoi-Khoin en die Nederlanders, hetsy verbyvaarders op besoek, of handelsgeselskappe in die binneland in, was sporadies van aard - dit was maar 'n skermoefening waardeur kennis van mekaar, en die tale wat gebruik is, op die agtergrond geskuif is. Ander doelwitte was belangriker. Die naarstiglike gesoek om vleis in die hande te kry, het in elk geval 'n soort toegespitse taalgebruik genoodsaak, omdat dit gefokus het op beperkte gespreksonderwerpe (soos in die geval van boeba ${ }^{4}$ ). Hierdie soort taalkontak kon hoogstens 'n rudimentêre soort aanleerderstaal tot gevolg gehad het.

Situasies wat meer bevorderlik was vir taalaanleer en wedersydse taalbeïnvloeding, maar van 'n heeltemal ander aard, het wel tussen die Khoi-Khoin en die vryburgerboere voorgekom. Hierdie twee groepe het byvoorbeeld saamgespan om die heerssugtige Kompanjie te uitoorlê. Tussen hulle het daar, ironies, 'n effense vertrouensverhouding ontstaan met hulle deelname aan 'n onregmatige veehandel in die vroeë Kaapse gemeenskap veral na 1690 (Elphick en Malherbe 1989:19). 'n Heining wat Van Riebeeck vroeër laat aanplant het om die twee groepe uitmekaar te hou, het nie in sy doel geslaag nie. Die kontakgeleenthede wat uit hierdie onwettige handeldryf gevolg het, en lank volgehou is, was nie ideaal vir beduidende wedersydse taalbeïnvloeding nie, maar was meer doeltreffend as ander sporadiese ontmoetings.

\footnotetext{
${ }^{4}$ Dit is interessant, soos Nienaber (1964:198) vermeld, dat boeba die woord is wat die Khoi-Khoin vir hulle beeste gebruik het wat hulle aan die Kompanjie wou verkoop. Die maer beeste. (Dalk omdat die Hollanders die klanknabootsing verstaan.) Hulle kosbaarder beeste was onder ander Khoi-name bekend.
} 


\subsection{Vyandigheid, onsekerheid en verydeling}

Vyandigheid tussen die Khoi-Khoin en die nedersetters was eerder die reël as die uitsondering, en het sekerlik meer as enige ander rede bygedra tot die gebrekkige aanleer van die nedersetters se taal deur die Khoi-Khoin. Kontaksituasies wat in 'n vyandige atmosfeer plaasvind, is nie bevorderlik vir die gee-en-neem-gesindheid wat ideale taalaanleer bevorder nie. Terwyl die Kompanjie in die Khoi-Khoin geïnteresseerd was sodat daar in die verbygaande vlote se vleisbehoeftes voldoen kon word, het die Khoi-Khoin maar uiters halfhartig meegedoen aan hierdie groeiende mark (Elphick en Malherbe 1989:10). 'n Groot gedeelte van die kontaktyd tussen die vryburgerboere en die Khoi-Khoin, veral toe die afsonderlike stamverbande nog bestaan het, het in 'n atmosfeer van agterdog, wantroue en vyandigheid plaasgevind. Dit was verstaanbaar - hulle het meegeding om dieselfde voedselbron, en die Kompanjie het verder die atmosfeer vertroebel deur uiterste druk by tye toe te pas om vee van die Khoi-Khoin te bekom, terwyl die Khoi-Khoin-stamme juis hulle ekonomie op veebesit ${ }^{5}$ gebaseer het. Die Khoi-Khoin het verspreid oor die skiereiland en omgewing gewoon toe die nedersetters daar aangekom het - "perhaps about 50000 in the whole of the southwestern Cape", skryf Elphick en Malherbe (1989:3). Mededinging om grond was nog 'n rede vir vyandigheid. Die stamme wat hierbo ter sprake gekom het (1.1), die Goringhaikwa, Van Riebeeck se Kaapmans, het byvoorbeeld in die sentrale gedeelte, om Tafelberg gewoon. Hulle bure was die Gorachoukwa, die mense van kaptein Gora, wat in Van Riebeeck se tyd 'n dagreis noord-oos van die kasteel, “achter't Lupaertsgeberchte (Tygerberg), gebly het (Nienaber 1989:402).

In die eerste tyd nadat die vryburgerplase toegeken is, het daar van die Khoi-Khoin se kant af ook direkte vyandigheid teenoor die vryburgerboere geheers. Van Riebeeck vermeld spesifiek in 1662 in sy aanbevelings (memorie) aan sy opvolger dat die Goringhaikwa en die vryburgers nie om een vuur gesit het nie (Nienaber 1989:417). Die Khoi-Khoin wou duidelik teenoor die boere hulle protes oor die boerderybedrywighede op hulle tradisionele weidinggronde manifesteer. Die vryburgers het weer van hulle kant af die Khoi-Khoin laat verstaan dat hulle aandring op respek vir hulle eiendom en produkte.

Die tweede oorlog teen die Kompanjie (1673-1677) het sleg afgeloop vir die Khoi-Khoin. Daarna was die Khoi-Khoin nie meer 'n militêre gevaar vir die kolonie nie, en, volgens Elphick en Malherbe (1989:13), het die VOC se houding sodanig verander dat hy begin het "to impinge on Khoikhoi sovereignty in many ways - military, diplomatic, economic and judicial" (Elphick en Malherbe 1989:13). Die Kaap het te Hollands begin word vir die KhoiKhoin, en hulle het dié streek begin verlaat. Kontakgeleenthede met die taal van die nedersetters sou eers weer later, in die binneland, opgeneem word.

Die Goringhaikwa het teen ongeveer 1687 die Wes-Kaap verlaat. Grondbesit kon hulle nie meer daar hou nie. Hulle het in 1672 hulle grond (en meer nog) aan die Kompanjie verkoop (Nienaber 1989:417), en daarmee ook konfrontasie daaroor begin beëindig. Onafhanklike Khoi-Khoin-middelmanentrepreneurs het hulle na die tweede oorlog suksesvol begin vestig. Dit het waarskynlik begin met Klaas (of Dorha, van die westelike Chainoukwa stam). Kennis

\footnotetext{
${ }^{5}$ Die pastorale boerderystelsel, skryf Elphic en Malherbe $\left(1989^{2}: 6\right)$, was 'n uiters onstabiele soort boerdery wat na rampe en veeverlies tot veeroof en oorloë aanleiding gegee het.
} 
van Nederlands was 'n voorvereiste in hulle onderhandelinge met die amptenare. In 1693 het Van der Stel, nogal kontroversieel, 'n einde aan die tussengangersbedryf gemaak. Daarmee was die geleentheid vir die Khoi-Khoin om Nederlands as 'n handeldryftaal te kon gebruik, om Nederlands beter te beheer, en om Nederlanders se taalgebruik te beïnvloed, iets van die verlede (Elphick en Malherbe 1989:13).

Die Khoi-Khoin wat nog teen 1700 in die Wes-Kaap was, en wat vir hulle 'n bestaan uitgekerf het wat by die Kaapse strukture ingeskakel het, sou 'n beter kennis van Kaapse Nederlands gehad het, byvoorbeeld as arbeiders op plase (hoewel daar slawe ook was), en nader aan Kaapstad, as kruiers op die hawe, werknemers in die gasvryheidsbedryf, wadrywers, briewebestellers, boodskappers, ensovoorts (Elphick en Malherbe 1989:16-18; Ponelis 1993:11). Die Kaap het stadigaan weer begin om vir hulle 'n tuiste te word, en het hulle op hierdie manier huisvesting gevind wat die ou stamme nie meer kon bied nie. Die pokkeepidemie van $1713^{6}$ met sy katastrofiese gevolge vir die Khoi-Khoin (en in 'n mindere mate vir die nedersetters ook) het hulle egter opnuut na 'n ander heenkome laat soek. Daar is berig dat net een Khoi-Khoin uit tien die pokke-epidemie oorleef het, en verwysings na die KhoiKhoin het vir 'n aantal jare selfs opgehou (Elphick en Malherbe 1989:21; Elphick 1985:234). Die groot aantal sterftes, en die vrees vir 'n volgende epidemie, was nóg 'n rede waarom die Khoi-Khoin hulle tradisionele woongebied prysgegee het, en in groot getalle begin wegtrek het uit die Wes-Kaap. Die afsonderlike Khoi-Khoin-stamme se verblyf in die Wes-Kaap het tot 'n einde begin kom. Hulle het na die oosgrensgebied toe verhuis, 'n skuif wat uiteindelik belangrike gevolge vir die tale in daardie gebied ingehou het.

\subsection{Doeltreffender taalaanleer}

Steyn (1980:107) skryf dat die Khoi-Khoin Nederlands vinniger aangeleer het nadat hulle op die vryburgerplase "vir kos en tabak ... gaan vee oppas, koring sny of waens dryf, terwyl die vroue kom kinders oppas het." Die Kompanjiebeleid het hierdie skuif egter bemoeilik. In sy 1662-memorie stel Van Riebeeck voor hoe die Kompanjie "meer onafhanklik van die inheemse mense kan word," skryf Nienaber (1989:21). Slawe-arbeid moet eerder gebruik word, is sy oplossing. Giliomee en Mbenga (2007:62) verwys na besluite wat 'n vyftig jaar later, in 1716 aan die Kaap oor die arbeidskwessie geneem is, besluite wat met die Van Riebeeck-visie klop. Daardie besluite het daartoe aanleiding gegee dat "die kolonie op slawearbeid" gebou sou word, wys hulle uit. (Vgl. ook Giliomee 2009:9;12.) Immigrasie uit Nederland is aan die arbeidskwessie gehaak, en al in 1706 gestaak, omdat daar genoeg slawe aan die Kaap was. Daardie besluit is nie in 1716 herroep nie (Steyn 1980:110). Die taalgevolge van dié besluit (wat nie waterdig afgedwing kon word nie), is interessant. Laat in die sewentiende eeu is dit omseil, veral na 1670, in die buitedistrikte Stellenbosch en Drakenstein (Paarl). Toé eers het beduidende kontak tussen Khoi-Khoin en boere begin plaasvind: "Europeans did not hire Khoikhoi as herders or shepherds before the 1670s" (Elphick en Malherbe 1989:16). In die buitedistrikte was daar minder slawe as nader aan Kaapstad, en die Khoi-Khoin het in 'n arbeidsbehoefte voldoen. 'n Situasie soortgelyk aan wat later, in die agtiende eeu, in die naburige oosgrensgebied sou heers, kon hier gevind word. In

\footnotetext{
${ }^{6}$ Steyn (1980:110) skryf dat die blanke bevolking in 1712, 1939 was, maar na die pokke-epidemie in 1716 net 1697. Met die epidemie van 1755 het die blanke bevolking van 5510 tot 5123 gedaal. (Vgl. ook Elphic en Malherbe $\left(1989^{2}: 21\right)$.)
} 
die kontaksituasies op die plase reik die beïnvloeding wyer as net taaloordrag. Die tradisionele manier van naamgewing is ook deur hierdie intensiewer kontak geraak. Steyn (1980:107; ook Ponelis 1993:486;488-489) wys daarop dat die Khoi-Khoin deur hierdie kontak ook voorname gekry het soos Frans, Dikkop, Jager, ensovoorts (sekere vanne weer, verraai 'n blanke bloedlyn. (Ponelis (1993:41), met verwysing na Heese).

\section{Khoi-Khoin en vryburgers na 1700}

\subsection{Die intrek in die binneland}

Die veeboere en die Khoi-Khoin het twee redes gedeel waarom hulle die Wes-Kaap verlaat het. Die een was die gebrek aan weiding vir hulle vee, en die ander een was hulle struweling met die VOC. In verband met die weiding vir hulle vee, verwys Louw (1948:94) na die krygsraad van Stellenbosch (1726) se bevinding, nl. dat die boere die Stellenboschdistrik verlaat het "om schaarsheid der weide". Die weiveld was vir hulle vee nodig (want die troppe was dikwels te groot vir die plase), daarom word in hierdie hoofstuk van dié boere, 'n voortsetting van die vryburgerboere, gepraat as veeboere. (Geskiedskrywers praat ook van hulle as trekboere.)

In die oosgrensgebied, wys Giliomee en Mbenga (2007:67) daarop, was daar ook swerftrekkers ('n term van Du Plessis 2011) bedrywig, wat eerder 'n nomadiese soort jagtersbestaan gevoer het, en nie veeboere was nie. Die swerftrekkers het dikwels oorleef deur by Khoi-Khoin-groepe in te skakel, en het soos hulle geleef wat kleredrag (velklere), kos, eetgewoontes en veldgereedskapgebruik betref. Baie swerftrekkers het voor die veeboere al in die binneland inbeweeg, sommiges gelyktydig met hulle. Dit het soms gebeur dat hierdie swerftrekkers aangesluit het by die meer georganiseerde veeboergemeenskap, en selfs later, met die volgende uitbreidingsfase van Afrikaans, het hulle met die Groot Trek saamgetrek. Vanselfsprekend sou talle swerftrekkers Khoi as 'n aanleerderstaal leer praat het.

'n Kwart van die sowat 1600 vryburgers teen 1700 was knegte (400) (teenoor sowat 500 vryburgerboere ). Die knegte het nie 'n belangrike rol in die boeresamelewing gespeel nie. Op die plase het hulle in buitegeboue geslaap. Baie van hulle het swerftrekkers geword (Giliomee 2009:19).

Die veeboere het die hele oosgrensgebied baie vinnig beset. Die Graaff-Reinet distrik is in 1785 al gestig. Die veeboere het ook nie noodwendig in een distrik bly woon nie, en hierdie onderlinge mobiliteit het ook meegewerk aan die vorming van Oosgrensafrikaans deur verskille gelyk te maak. Louis Tregardt, die latere trekleier (wat sy naam op dié manier gespel het), wat in die Swellendamdistrik gebore is (1783), in die Paarl gedoop is, en in die Somersetdistrik (oos van Graaff-Reinet) gewoon het, is 'n goeie voorbeeld (Visagie 2011:500).

\subsection{Afgrensing van die oosgrensgebied}

Die Hottentots-Hollandberge, en die aansluitende berge ten noorde daarvan, het 'n betekenisvolle grens met die Wes-Kaap gevorm. Vanselfsprekend nie 'n absolute grens nie, en 'n bepaalde mate van taalkontak sou steeds tussen die grensgebiede van Stellenbosch en Paarl 
(Drakenstein), wes van die Hottentots-Hollandberge en Tulbach, Worcester, Swellendam en die aangrensende distrikte ooswaarts daarvan, behou word, omdat die afstande nie te groot was nie. Louw, met verwysing na die historikus Van der Merwe, onderstreep die belangrike rol van die Hottentots-Hollandberge in die agtiende eeu in die relatiewe isolasie van die oosgrensgebied. Sy taalkaartgegewens, wat Afrikaans betref, dui ook daarop. Die roete oor die berge dui op 'n "langsame beweging" van taalverskynsels, die roete langs die kus, "daarenteen op vinniger verskuiwing" (Louw 1948:95). "En die nakomeling kan vandag moeilik begryp hoe 'n ossewa oor die ou Hottentots-Holland-kloof kon gebring word," beaam Bosman $\left(1928^{2}: 122\right)$ in verband met hierdie grens. Noord-westelik het die uitbreidings teen 1760 tot aan die Olifantsrivier gevorder, en ooswaarts is die streek afgegrens deur die Xhosagebiede, noordwes van Graaff-Reinet.

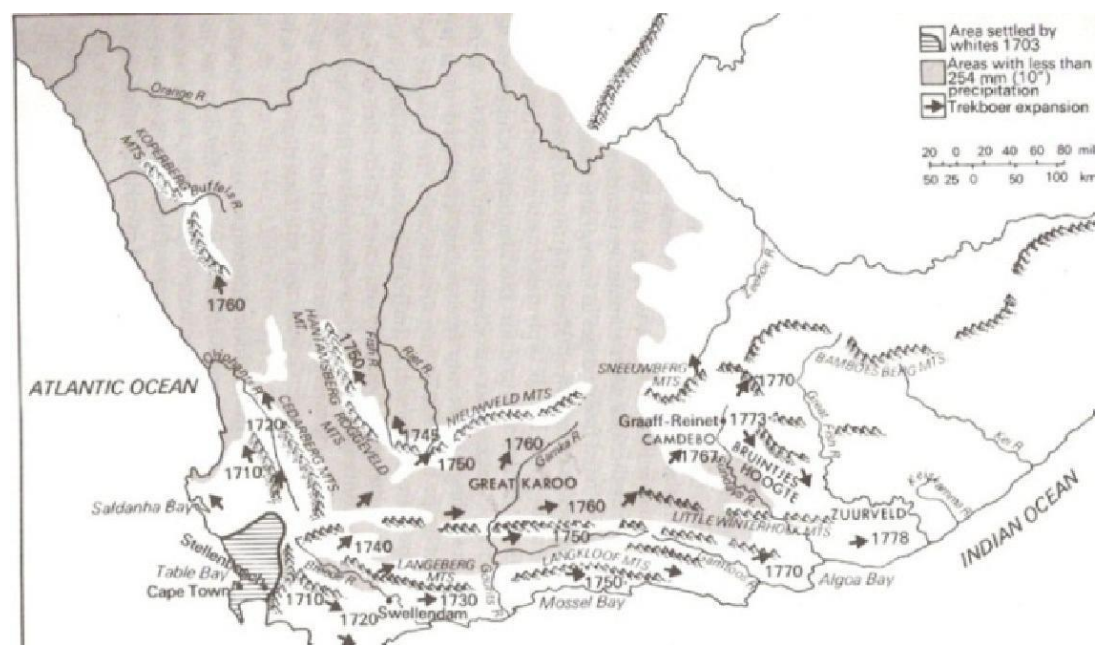

Kaart 1: Die besetting van die oosgrensgebied sedert 1700 (Guelke 1989:68).

\subsection{Gunstige omstandighede vir betekenisvolle taalkontak}

Omstandighede vir betekenisvolle taalkontak tussen die veeboere en Khoi-Khoin in die oosgrensgebied, en wat bepalend is vir die gevolgtrekkings wat daaroor gemaak kan word (vgl. Du Plessis 1994:123), was ná 1700 gunstiger in die Wes-Kaap. Die hoofgroepe van die bewoners van die oosgrensgebied, die veeboere en die Wes-Kaapse Khoi-Khoin, asook etlike Khoi-Khoin-stamme wat reeds in die binneland gewoon het, het beide gebaat by die nouer kontakgeleenthede, maar miskien nie in 'n gelyke mate nie. As gevolg van die afgesonderdheid van die gebied was die inwoners van die oosgrens in talle opsigte op mekaar aangewese. Uitgebreide gesinne het sentraal in die oosgrensgemeenskap gestaan. 'n Man was aan die hoof van so 'n gesin, ondersteun deur sy seun(s) en skoonseun(s). As een van die ouers te sterwe kom, is daar gou weer tot 'n nuwe huwelik oorgegaan, en is daar dikwels 'n nuwe stel kinders by 'n bestaande stel geïnkorporeer. 'n Groot aantal kinders, tien of meer per gesin, was in elk geval aan die orde van die dag (Raidt 1995:132). Die uitwisseling van weidingkennis, veldkennis, beskermingstrategieë, ensovoorts, wat nodig was vir'n veilige bestaan, is buite die gesin, ook met die Khoi-Khoin bespreek. Die onderlinge afhanklikheid van die Khoi-Khoin en die veeboere word byvoorbeeld geïllustreer deurdat die veeboere (volgens 'n berig van Menzel uit ongeveer 1730, waarna Elphick en Malherbe (1989:24) verwys), dikwels verkies het om in die omgewing van Khoin-Khoin-krale te gaan woon. Dit het hulle toegang gegee tot 
waterbronne, weiding en arbeid. Die Khoi-Khoin, weer, het gebaat by die beskerming wat hulle geniet het teen aanvalle van rowers. Soms was die identifisering met die veeboere so nou, dat van die Khoi-Khoin hulleself as "boere" beskryf het (Elphick en Malherbe 1989:24). Hierdie vertroudheid, wat nie veralgemeen kan word nie, het 'n ideale situasie geskep vir die verdere aanleer van die veeboere se taal, en beïnvloeding van die veeboere deur die aangeleerde taal. Die Khoi-Khoin se teenwoordigheid in die oosgrensgebied spreek vandag nog uit die groot aantal plekname wat beide groepe se geskiedenis gedokumenteer het, asook vervormings van gebruiksname, veral in Oosgrensafrikaans, wat weer lig op die betrokke aanleerproses werp. 'n Khoi-spreker, met bietjie kennis van Oosgrensafrikaans, sou [/haru] byvoorbeeld verduidelik het as biesie. Hoorders praat dan van harubiesie, en waar die materiaal gebruik word om 'n eenvoudige huis mee op te rig, van 'n harubiesiehuis, wat later 'n hartbeeshuis word (Nienaber 1964:206). In hierdie geval dui die oorgelewerde name daarop dat die oordrag oorspronklik van Khoi na Oosgrensafrikaans toe was.

\subsection{Dokumentering van Oosgrensafrikaans}

Oosgrensafrikaans was 'n spreektaal en nooit 'n skryftaal nie, en is hoegenaamd nie eenvormig gepraat nie - 'n situasie wat voortgesit is uit die Wes-Kaap. Daar was dit 'n "colloquial Dutch that functioned within the multilingual Cape speech community and not the formal, written variety" (Ponelis 1993:25). Briefskrywers het Oosgrensafrikaans, miskien onbewustelik, goed gedokumenteer deurdat hulle dikwels probeer het om Nederlandse briewe te skryf, maar dan moes terugval op die spreektaal. Van Oordt $(1947-48 ; 1949)$ se data dui hierdie gebruik goed aan. (Taalbesonderhede van Oosgrensafrikaans, wat nie hier ter sprake kom nie, is verder uitgewys deur o.a. Scholtz 1963, 1972; Nienaber 1942). Mentzel, wat gedurende 1733 tot 1741 in diens van die VOC was, het ook die groot verskil waargeneem tussen die plattelandse boere se taal en "suiwer Hollands" (Raidt 1976:150). Die grootste gros van die kenmerke van die veeboere se omgangstaal teen die einde van die 18de eeu kan in teenswoordige (Standaard)afrikaans uitgewys word. Agter die taal van byvoorbeeld die weduwee De Bruijn se briewe, van 1795, sê Raidt (1976:119), skuil haar spreektaal "wat min of meer soos hedendaagse Afrikaans moes geklink het." (Uit 'n ontleding van briewe wat deur vrouens geskryf is tussen 1710 en 1805, maak Raidt (1995:131 e.v.) nog sulke afleidings.) Scholtz (1880:57) wys egter daarop dat daar ook vorme in die 18de eeu en nog vir 'n deel van die 19de eeu bestaan het, maar in hedendaagse "Afrikaans nie meer gehoor word nie".

\subsection{Samestelling van Oosgrensafrikaans}

Oosgrensafrikaans het sy karakter gekry deurdat mense van verskillende herkoms vryburgerboere geword het (Ponelis 1993:9), in gesinsverbande waar ander tale ook 'n rol gespeel het, en deur beïnvloeding van Khoi, hetsy oorgedra uit die Wes-Kaap as KhoiNederlands, of Khoi, soos dit nog binne stamverbande in die begin van die oosgrenstyd gepraat is, asook'n wye spektrum tussenvorme.

Binne gesinsverband het verskeie tale 'n rol gespeel omdat die tekort aan vrouens mans teen die einde van die sewentiende eeu genoodsaak het om met vrouens van Kaapse afkoms te trou, totdat hierdie behoefte uit eie geledere aangevul is (Guelke (1989:82) skryf: "The white population was mainly native born by 1731 ..."). Ponelis (1993:9) wys daarop dat 39\% van 
die vrouens van vryliede (waarvan sowat 33\% boere was), tussen 1657 en 1707 van Kaapse herkoms was, 'n "feminine element not linked by birth to the Dutch network" (Ponelis 1993:10; vgl. ook Giliomee 2009: 37). Hierdie vrouens sou nuwe moedertaalelemente in hulle huishoudings ingevoer het. In Batavia, by gemengde huwelike, "children were brought up in the cultural sphere of the wife," en het hulle nie Nederlands gepraat nie (Ponelis 1993:104). Aan die oosgrens, was die taal van die vader die beslissende faktor. Waar blanke oosgrensboere saam met Khoi-Khoin geleef het, soos wat by ongeveer $10 \%$ van die boere die geval was, het die kinders Oosgrensafrikaans as hulle hooftaal gepraat (Ponelis 1993:40-41).

Die Khoi-Khoin in die binneland, anders as baie van hulle voorouers in die Wes-Kaap tydens Van Riebeeck se tyd, was verarm, en, met min uitsonderings, op die veeboere aangewese vir 'n bestaan (Elphick en Malherbe 1989:16-22). Baie veeboere het ook maar 'n sukkelbestaan gevoer. Guelke (1989:92) skryf: "Few stock farmers were wealthy". Khoi-Khoin het hulle eie vee ook op die veeboerplase aangehou, waardeur wedersydse langdurige kontak verseker is ${ }^{7}$. Elphick en Malherbe (1989:28) haal Barrow aan wat in 1779 sê "[...] there were no independent 'kraals' in Graaff-Reinet, nor even 'a score of individuals who are not actually in the service of the Dutch." $\mathrm{Na}$ mate die verbintenisse van individuele Khoi-Khoin met afsonderlike stamme toenemend gedisintegreer het, het blootstelling aan die veeboere se taal op die plase toegeneem, meer intensief as wat dit die geval was aan die einde van die eerste vyftigjaartydperk. Die getalle wat hier, in die agtiende eeu, ter sprake was, aan albei kante, was ook baie groter. Op die plase was taalkontak intensief. Hierdie huishoudings het taamlike hegte kontakeenhede gevorm wat bestaan het uit die boer en sy familie, en die plaaswerkers (Giliomee 2009:37). Raidt (1995:131) maak melding van 'n opmerking van Lichtenstein in 1812 oor die goeie beheer wat 'n vrou in die binneland van Khoi gehad het. Oor die algemeen het plaaswerkers die oosgrensbewoners se taal aangepas en onderling gebruik as kommunikasietaal. Dit het die Khoi-Khoin die geleentheid gegee om as werknemers oor 'n hele reeks verskillende terreine hulle taalstempel te kon afdruk. Hulle was byvoorbeeld veewagters, plaaswerkers, wadrywers, jagters, huishulpe, kinderoppassers, ensovoorts. Hier was die kontak langdurig en het dit 'n wye spektrum van werk- en kulturele elemente behels.

\subsection{Die kommandostelsel}

Die kommandostelsel wat vanaf 1715 in die oosgrensgebied gebruik is, het ook 'n belangrike kommunikasierol gespeel tussen die bewoners van die oosgrensgebied. Gebeur dit dat die verantwoordelike veeboere nie op kommandodiens kon gaan nie, kon plaasvervangers gestuur word, waaronder ook Khoi-Khoin-plaaswerkers. In 'n kommando van 250 man (1774), merk Elphick en Malherbe (1989:26) op: "Bastaards and Khoisan formed more than half." Vir die Khoi-Khoin was kommandodiens 'n statusgebeurtenis, en ook 'n geleentheid om ou geskille met vorige vyande te besleg, en in buit te deel. Gewoontes en taalgebruik is deur hierdie kontak wedersyds uitgeruil (Giliomee 2009:62-63).

\footnotetext{
${ }^{7}$ Die taalaanleersituasie op die veeboerplase kom ooreen met die $e$-tipe aanleeromstandighede wat Roberge (1995:69) voorhou waaronder spontane taalverwerwing kan plaasvind, nl. "indentured, impressed ... labour systems in colonial settings."
} 


\subsection{Isolasie van die bewoners van die oosgrensgebied}

Isolasie van 'n streek help die ontwikkeling van die taal wat daar gepraat word. Eksterne invloede bly daarbuite, en interne variasie begin nivelleer. Sowel die Khoi-Khoin as die veeboere was na hulle vertrek uit die Wes-Kaap genoodsaak om hulle toekoms in die nuwe landstreek te vind. Die veeboere kon nie teruggaan en hulle soort boerdery in die Wes-Kaap gaan voortsit nie. In die Wes-Kaap sou die Khoi-Khoin van die oosgrensgebied met hulle terugkoms in 'n nog groter mate vreemdelinge wees as vroeër. Die veeboere se besetting van die binneland, sê Elphick en Malherbe (1989:8), "did not greatly effect the southwestern Cape; it originated on the fringes of the colony in the 1690s and moved inland ..." Die veeboere het nuwe belange ontwikkel. Spontane skakeling tussen die Kaapstadomgewing en die bewoners van die oosgrens, die Khoi-Khoin en die veeboere, het al hoe skaarser geword. Behalwe die Hottentots-Hollandberge het afstande ook 'n rol gespeel om die oosgrensbewoners te isoleer. Louw (1948:95) wys daarop dat 'n reis van Graaff-Reinet na Kaapstad en terug "twee tot drie maande" geduur het. Handelstransaksies met verbygaande skepe, en selfs met handelaars in Kaapstad, was iets wat eers goed deurdink is. Die hele familie moes so 'n tog meemaak. Om geld vir handelsware (velle, ivoor, graan, ens.) te kry, was nie altyd bevredigend nie. Hoewel die boere afhanklik was van kruit, gewere, waens, gereedskap, ensovoorts, en belastings met geld moes betaal, kon geld kon nie altyd in die binneland gebruik word nie. Reisigers soos Menzel het soms nogal uit die hoogte berig oor hoe hierdie gesinne op die plase lewe, oor hoe hulle praat, en waaroor gesprekke handel.

Die oosgrenswêreld het in talle opsigte anders daar uitgesien as die Wes-Kaapse omgewing. Nuwe gesprekstemas het onder nuwe omstandighede belangrik geword, en nuwe sake is leer ken. Bestaande woorde moes aangepaste rolle vervul, of nuwe woorde moes vir nuwe sake bedink word. Raidt (1976:156-162) wys op sulke gevalle, soos fontein, plaas, ystervark, skof, sommige al voor die oosgrenstyd bekend. Eers in die oosgrensgebied kon Khoi-Khoinplaasarbeiders in beduidende getalle hierdie woorde leer ken. Die vroeë Wes-Kaapse aanleerdersvariëteit van die Khoi-Khoin is in die oosgrensgebied op verskeie maniere gewysig.

$\mathrm{Na} 1800$ is die taalisolasie van die inwoners van die oosgrensgebied verbreek deurdat Engels stadigaan 'n rol begin speel het. Die Veeboere van die Kamdebo, Graaff-Reinet en die Angolabaai-omgewing het teen 1820 begin deelneem aan die ekonomie van die Britse handelswêreld en die taal wat daarmee gepaard gegaan het (Elphick en Malherbe 1989:43).

\subsection{Antagonisme en selfstandigheid}

Vyandelikhede het steeds tussen Khoi-Khoin en veeboere voorgekom. Taalintegrasie het egter al so ver gevorder dat, anders as gedurende die sewentiende eeu, konfrontasie en onafhanklikheid die gevolge van taalkontak nie meer kon onderbreek nie. Gedurende die eerste 50 jaar na Van Riebeeck se koms, was daar tydens vyandelikhede min geleentheid vir natuurlike taalkontak, hier was die konfrontasietaal nou Oosgrensafrikaans. Die Khoi-Khoin was baie meer vertroud met die taal van hulle teenstaanders as wat dit gedurende die eerste 50 jaar die geval was. 


\section{9 'n Middelklas Khoi-Khoin}

Khoi-Khoin het ook ander inkomstebronne gevind sodat 'n Khoi-Khoin middelklas ontstaan het wat nie afhanklik van plaasarbeid was nie. Hierdie middelklas het bestaan uit Khoi-Khoin en mense van gemengde bloed: ambagslui uit die sendingstasies, soldate, jagters, predikers, boere, transportryers, ensovoorts. Op grond van ordonnansie 50 wat in 1828 uitgevaardig is, en geldig gebly het tot 1841 , kon Khoi-Khoin vir die eerste keer weer grondeienaars word (Elphick en Malherbe 1989:47-49). Die onafhanklikheid van hierdie middelklas het te laat gekom om die natuurlike verbreiding van Oosgrensafrikaans te verhoed en Khoi te laat herleef. Oosgrensafrikaans het in der waarheid 'n funksieuitbreiding bygekry deur ook op hierdie terrein gebruik te word. Na mate hierdie middelklas onafhanklik geword het, het hulle uit die direkte kontaksfeer van die boere beweeg. Selfstandigheid sou egter nie 'n verskil maak aan die aanleerderstaal van die Khoi-Khoin nie - op al die plase, en daarbuite soos op die sendingstasies, is Oosgrensafrikaans steeds gebruik.

In die Katriviernedersetting (vir besonderhede van die nedersetting, vgl. Giliomee en Mbenga 2007:141 e.v.) was 'n Aanleerdersafrikaans bekend (waaroor o.a. Scholtz 1965:59-67; 294300 skryf), soos ook op die sendingstasies. "Op die sendingstasies was Afrikaans-Hollands reeds vroeg die voertaal", skryf Belcher (1987:27). Hy wys ook op die oorgang van "Hollands na Afrikaans" wat gesien kan word in die publikasies wat op Genadendal gedruk is (Belcher 1987:29). Steyn (1980:107-8) verwys ook na die aanleer van Nederlands op Genadendal en Baviaanskloof.

Vir 'n groot aantal Khoi-Khoin het die Kaapse Korps ook 'n beter vooruitsig gebied. Hulle kon meer geld verdien as op die plase, en na 21 jaar diens ook 'n pensioen kry. Daar was plaasarbeiders wat gedros het om by die Korps aan te sluit (Elphick en Malherbe 1989:35-38). Die lede wat van plase af gekom het, het in elk geval Oosgrensafrikaans in die Korps gebruik.

\section{Gevalle van taalbeïnvloeding in die oosgrensgebied}

\subsection{Datering van beïnvloeding}

Dit is nie moontlik om taalverskynsels wat wedersydse beïnvloeding vertoon, soos by die immigrantegroepe in die oosgrensgebied, onomstootlik te dateer nie. 'n Rekonstruksie van die periode van taalkontak, waarvan meer bekend is, en die omstandighede wat daarmee gepaard gegaan het (soos in die voorafgaande gedeelte gedoen is), verskaf die beste aanduiding van die tydsgleuf waarin beïnvloeding plaasgevind het.

Geskrewe gegewens oor taalverskynsels se eerste voorkoms in geskrewe Oosgrensafrikaans, sê niks oor die vroeëre voorkoms daarvan in spreektaalvorm nie. ("There are good reasons to be sceptical of the received chronology," sê Roberge (1995:72) daarvan.) Skriftelike optekeninge van tale in kontaksituasies verskaf wel belangrike inligting oor taalstrukture, en 'n aantal interessante neigings oor sosiale strominge, en onderlinge verhoudings tussen sprekers, kan ook daaruit afgelei word. 
Verskillende soorte beïnvloeding kan onderskei word. Hier word vervolgens aandag gegee aan gevalle van beïnvloeding van Oosgrensafrikaans deur Khoi (5.2), en aan gevalle wat heelwaarskynlik voor die sewentiene eeu aan die Kaap gebruik is, deur sowel sprekers van Khoi en van latere Oosgrensafrikaans, maar waarvan die wyer opname daarvan in Oosgrensafrikaans eers daarna deur Khoi gestimuleer is (5.3).

\subsection{Enkele gevalle van beïnvloeding deur Khoi}

Verskillende strukture met Khoi as basis, kon Oosgrensafrikaans beïnvloed het. Een soort hou verband met die opvallende pidgin-tipe aanleerdersvorme van die Khoi-Khoin (en via die Khoi-Khoin ook die slawe) wat al voor 1700 opgeteken is, en die gedeeltelike uitbreiding daarvan na volwaardiger Nederlands toe. Eers het die sprekers van Oosgrensafrikaans hierdie kenmerkende vorme vermy, maar later tog oor 'n breë front aanvaar, soos die gebruik daarvan in oosgrensbriewe en ander dokumente aandui. Die vermydingsfase dui op die stigmatisering van tiperende Khoi-Khoin-taalgebruik. Die skryftaalgegewens illustreer dit, en is van waarde om te wys dat beïnvloeding van onder uit die sosiale verdeling wel vanaf ' $n$ bepaalde tydstip aanvaarbaar geword het, en dat die ou klasseverskille begin verdwyn het (vgl. Giliomee 2009:34; Guelke 1989:82).

Die geval van ons in onderwerpsposisie in Oosgrensafrikaans illustreer die bostaande waarneming. Van die vroegste dokumente oor Khoi-Khoin aanleerders ${ }^{8}$ se Nederlands wys op die gebruik van ons in onderwerpsposisie (vgl. 2.1 hierbo), in byvoorbeeld die opgetekende sinnetjie uit 1672, ons $u$ kelum (ons sal jou keel afsny). Aanleerders hef maklik die onderskeid tussen onderwerp en voorwerp op (Markey 1982; Ponelis 1988; Ponelis 1993:27-30; Van Rensburg 1989); soos wat hier gebeur het. Volgens data van vroeg in die negentiende eeu (Ponelis 1993:30; 32) gebeur dit ook met ander aanleerders van Nederlands, later in SuidAfrika, soos slawe (ons/wij). (In hierdie studie val die fokus op Khoi, en slawe- en ander tale word, waar moontlik, net ter inligting gebruik.) Elders, waar Nederlands ook aangeleer word, word hierdie aanleerderstrategie van die gebruik van voorwerpe in onderwerpsposisie ook gevolg, soos Hesseling (1905:129 e.v.) asook Van Rossem en Van der Voort (1996:14; 49 e.v.) in Negerhollands gevind het (op die Maagde-eilande). Die verskynsel kom voor ten opsigte van mi/ik (in byvoorbeeld: mi jammer ju ek kry jou jammer), en wat ons betref, volgens Van Rossem en Van der Voort (1996:2). Volgens laasgenoemde: "Negerhollands ons ... corresponds to Dutch wij/ons/onze 'we/us/our"'. In Surinaams-Nederlands (Cairo 1977:30 e.v.) kom $m i$ ook in onderwerpsposisie voor.

Al het ander aanleerders aan die Kaap ook ons in onderwerpsposisie gebruik, is dit vroeg reeds (vgl. die data uit 1672) aan Khoi-Nederlands gekoppel. Die Khoi-Khoin het hierdie gebruik behou: ons sel jou kost geven (1706); ons wil dat niet doen (1707) (Scholtz 1963:2627, met verwysing na Franken 1953.) Ons in onderwerpsvorm het eers na die agtiende eeu deel van algemene Afrikaans geword. Die eerste optekening daarvan is deur Mentzel tussen 1733 en 1741gemaak (waarna Raidt 1976:150 verwys)), en is taamlik selfbewus geuiter. Daarna word die optekeninge meer (Raidt 1995:134). Ponelis (1993:218) het dit heel

\footnotetext{
${ }^{8}$ Voorbeelde van Slawe-Nederlands met ons in onderwerpsposisie kom ook voor. Die eerste optekenings dateer uit 1691 (Raidt 1976:112). Daar was egter baie minder slawe as Khoi-Khoin op die boereplase toe die beïnvloedingsmoontlikhede die sterkste was.
} 
waarskynlik reg as hy vermoed dat hierdie verskynsel aanvanklik gestigmatiseer was. Nog Khoi-aanleerdersvorme uit die Wes-Kaap het deel geword van Oosgrensafrikaans deurdat slawe en Khoi-Khoin hierdie vorme saamgebring het na die oosgensgebied toe. Sulke vorme is mettertyd gedestigmatiseer, en is eers in die agtiende eeu in Oosgrensafrikaans sodanig aanvaar dat dit skriftelik weergegee kan word. Aan die oosgrens het die norme vir geskikte taalgebruik onder druk van die Khoi-Khoin se aanleerdersvorme begin verander. "(P)ronouns like ons, julle and hulle in subjunctive function were highly stigmatised forms which were carefully avoided by whites," skryf Raidt (1995:133 e.v.). Nog gestigmatiseerde vorme, sê Raidt, is $u$, die indirekte aanspreeksvorm ${ }^{9}$ (ek vra vriendelik vir vader en moeder ... dat ek die geld wat ons van vader het), hom, ek, en wat (in plaas van die). Scholtz (1972:40) merk op dat hierdie en daardie ook "klaarblyklik as on-Nederlands" aangevoel is, en uit die skryftaal geweer is. Menzel het sy optekening oor ons op 'n plattelandse plaas gemaak, juis daar waar kontak met Khoi op sy intensiefste was.

Ander taalverskynsels kan saam met die ons-geval as tipies Khoi geklassifiseer word. KhoiNederlands se woordvolgordepatrone val hieronder (vgl. ook Ponelis 1993:313-314). Die sprekers van Oosgrensafrikaans kon dié patroon op dieselfde manier geïnkorporeer het as wat dit met ons die geval was. Den Besten (1989:34 e.v.) voer aan dat Khoi SOV-woordvolgorde, soos die Ten Rhyne-voorbeeld van 1671 illustreer (vgl. 2.1 hierbo), Die man my soon witte boeba geme (Die man sal my mooi wit beeste gee) die basis vir latere soortgelyke konstruksies in die aanleerdertaal van die slawe was, en dat Afrikaans ook vervolgens daardeur beïnvloed is. Hy maak ook 'n belangrike opmerking in verband met Nederlandssprekendes se taal in aanleersituasies: "Dutch foreignertalk can be described as 'invinitival Dutch"' sodat Nederlands dan SOV-volgorde, Ik jou niet begrijpen, moet vertoon, wat aansluit by die Khoiwoordvolgordestruktuur (Den Besten 1994:9).

Die geval van $d$-rotasering, in caerels (katels), wat in 1720 opgeteken is, is interessant. Ponelis (1993:160) identifiseer dit ook as Khoi-invloed, wat nie deurgevoer is na die latere Standaardafrikaans nie.

Den Besten $(1985$; 1986) was nogal geïnteresseerd in die voorkoms en herkoms van nie-2 in Afrikaans, wat ook in hierdie kategorie pas. Met die Khoi-ontkenningstruktuur in gedagte voer hy ook later aan: "im Khoekhoe (wird) das Negationswort ans Verb angehängt (also: SOVneg). Höchstwahrscheinlich ist also das afrikaanse satzfinale nie durch interferenz aus dem Khoekhoe entstanden ..." (Den Besten 1987b:15). Skriftelike verwysings na nie-2 trek eers na die begin van die agtiende eeu die aandag, en dan meestal soos gebruik deur Franse, Duitsers, maar ook deur boere (Ponelis 1993:474-475). Van Oordt (1950:88) wys daarop dat alhoewel niet-niet nog nie voor 1800 in veldwagtertekste voorkom nie, kom en as lid van die ontkenningsparadigma (onteenseglik Nederlands), wel voor. Na 1830 kom nie-2 frekwent in geskrewe tekste voor (Raidt 1976:192). Na sy besoek aan die Kaap in 1825 berig Teenstra dat die dubbele negatief toe al algemeen in gebruik is. In Khoi kom 'n dubbele negatief ook voor, en Den Besten voer die Afrikaanse gebruik daarheen terug. (Vgl. ook Ponelis (1993:474 e.v.) oor die herkoms van nie-2 in Afrikaans.) Dit is egter interessant om te sien dat tekste wat die gebruik van die Khoi-Khoin se Oosgrensafrikaans probeer weergee (deur Boniface en Meurant), wel nie-2 gebruik. In die

\footnotetext{
${ }^{9}$ Vgl. ook Den Besten $(1887 b, 2001)$ vir 'n bespreking van die indirekte aanspreekvorm.
} 
boer Bezuidenhout se taal (1851) kom nie-2 ook voor (vgl. Ponelis 1993:476). ${ }^{10}$ Waaroor daar wel sekerheid bestaan, op grond van geskrewe dokumente, is dat die veralgemening van die gebruik van nie-2 teruggevoer kan word na die oosgrensgebied toe. Daar het kontak met die oosgrensboere beïnvloeding gestimuleer, vanwaar dit in latere Standaardafrikaans gevestig is. Die feit dat nie-nie (teenoor niet-en, soos Van Oordt (1950:88) aantoon) so laat in die oosgrensliteratuur voorkom, word ook aan stigmatisering toegeskryf (Raidt 1976:192; 1995:137) en onderskryf die Khoi-Khoin-konnotasie daarmee.

In die Standaardafrikaanse perifrastiese besitskonstruksie, soos in hond se gedagte, kom se ooreen met Khoi -di-. Den Besten (1987b:14) skryf "die afrikaanse Struktur mag darum durch eine khoekhoesche Reinterpretierung der Niederländische Struktur entstanden sein." In Griekwa-Afrikaans, waar Khoi-invloed baie lank voortgeleef het, het hierdie konstruksie (hy se huis), beter bewaar gebly as elders. Die onmiddellike afleiding is dat dié besitskonstruksie in Standaardafrikaans onteenseglik van Khoi-herkoms is, en by hierdie groep ingedeel behoort te word. Hierdie konstruksie kan egter in Nederlands ook aangetoon word, asook in Maleis en Laagportugees (Den Besten 1987b:14; Ponelis 1993:229-244), en sou nie in die Kaap vreemd gewees het nie, sodat dit ook by die volgende groep ingedeel kan word. Gesien die verbreidheid van hierdie verskynsel in Griekwa-Afrikaans, en die afwesigheid van die ander betrokke tale in taalkontaksituasies in die oosgrens, lyk dit meer as waarskynlik dat Khoi in die oosgrensgebied verantwoordelik was vir die veralgemening daarvan in huidige Standaardafrikaans. (Vgl. ook Den Besten (1978:28-38).)

Afrikaans se tweetydsisteem (teenoor Nederlands wat vier tye onderskei) vertoon ook gevolge van kontak met Khoi (en met slawe) (Den Besten 1994:3). Roberge (1995:80) verwys na 'n opmerking van Lichtenstein, wat in 1803-1806 deur die binneland gereis het, oor die weglating van die hulpwerkwoorde van tyd, hebben en zijn, deur Khoi-Khoin. Roberge (1995) speur dit ook na in resente voorbeelde van Oranjerivierafrikaans, en koppel dit aan $g e-/ g a-$ wat van vroeg af aan in die Kaap as werkwoordprefiks tyd aangedui het.

\subsection{Gesamentlike beïnvloeding deur Khoi-Khoin en ander sprekers}

Met die inkorporeer van sekere algemene taalaanleerverskynsels in Oosgrensafrikaans, wat ook deur die Khoi-Khoin gebruik is, is dit anders gesteld as by die vorige groep. Hierdie verskynsels is nie as behorende tot Khoi herken en gestigmatiseer nie. Dit is waarskynlik daaraan toe te skryf dat dit nie alleen Khoi-Khoin is wat met hulle aanleer van Nederlands in die vroeë Kaap sulke aanleerdersverskynsels verwerf het nie. Hierdie verskynsels kan as algemene aanleerderspatrone getipeer word. Sonder 'n Nederlandse korrektief het die KhoiKhoin dit in hulle Aanleerdersnederlands algemeen gebruik, en na mate die Nederlandse voorbeeld in Oosgrensafrikaans verdwyn het, het die verbreiding daarvan toegeneem.

Daar bestaan baie getuienis dat taalaanleerders Nederlands aanleer sonder om die $-t$ aan woordeindes na 'n stemlose konsonant te gebruik (nag/nacht). Dit het gebeur in die Nederlandse Karibiese gebiede, en vanselfsprekend ook by die Khoi-Khoin en slawe aan die vroeë Kaap. Die Khoi-Khoin (en slawe) kon mede-verantwoordelik gewees het vir hierdie

\footnotetext{
${ }^{10}$ Wat die nie-2 kwessie egter kompliseer, is (i) dat dit nie in Griekwa-Afrikaans ('n voormalige Khoi-Khoin woongebied) voorkom nie, maar (ii) wel by Abu Bakr, in Moesliemafrikaans van die Wes-Kaap.
} 
verskynsel wat eers "rondom 1700 'n vaste kenmerk van Kaapse taal geword het" (Scholtz (1980:57-59). Sprekers van Nederlands kon egter ook so beïnvloed gewees het. Beide Ponelis (1991:70) en Hesseling (1923:126) wys daarop dat woorde sonder eind-t ook in die Nederlands van Maleissprekendes voorkom. Duisende tuisvaarders uit die Nederlandse ooste het met gereelde tussenposes aan die Kaap vertoef (De Ruyter en Kotze 2002), asook uitvaarders wat Nederlands nie goed kon praat nie. Hierdie verskynsel sou nie as Khoi-Khoingestigmatiseerd gewees het nie maar kon as 'n algemene verskynsel van die oosgrensinwoners se taal ervaar gewees het, sowel van die Khoi-Khoin as die veeboere.

Dieselfde geld waarskynlik vir die veralgemening van genusonderskeidings (vgl. Roberge (1995:78) vir die opheffing van genus- en ander onderskeidings) wat in verskeie groepe taalaanleerders, se taal kan voorkom, waaronder beide die Khoi-Khoin en die sprekers van Oosgrensafrikaans. Om hierdie sake nog meer kompleks te mak, is daar ook nog moedertaaldialeksprekers van Nederlands wat ook so praat. (Vgl. Scholtz (1980:54) vir die geskakeerdheid van Nederlands aan die Kaap.)

Die pad wat die - $t$ aan woordeindes geloop het, is waarskynlik ook gevolg met die vokalisering van die intervokaliese velêre frikatief (reën/regen), 'n proses wat "al teen 1800 ver gevorder was" (Scholtz 1980:57-59). Dieselfde geld vir die kongruensie tussen onderwerp en werkwoord wat maklik deur aanleerders opgehef word (byvoorbeeld wij is), soos dokumente van die taal van Khoi-Khoin, slawe en Hugenote aantoon. Ponelis (1993:410) sê hierdie verskynsel was teen die agtiende eeu 'n algemene kenmerk van Kaapse taal, wat volgens veldwagtersrapporte in die oosgrens algemeen geword het. "Dating: In the second half of the eigteenth century, concordial divergence was common, both in shorter letters and depositions" (Ponelis 1993:409). Dit was juis teen hierdie tyd dat byna die hele oosgrensgebied deur veeboere beset was, en dat die Khoi-Khoin al goed as werknemers by die boere ingeskakel het.

\section{Agternablik}

Teen 1830 was Khoi 'n taal wat skaars nog gepraat is. 'n Vorm van Oosgrensafrikaans het die Khoi-Khoin se taal grootliks verplaas, hoewel Khoi, en Khoi-Afrikaans, onuitwisbare spore op die veeboere se taal gelaat het. Die nóú taalverband tussen Khoi en die oosgrens is verbreek toe meer as 20000 veeboere uit die hele oosgrensgebied na 1830 noordwaarts weggetrek (Visagie 2011:14) en hulle oosgrenstaal met sy Khoi-invloede saamgeneem het na die noorde toe.

\section{Verwysings}

Belcher, R. 1987. Afrikaans en kommunikasie oor die kleurgrens. In Du Plessis, H.G.W. en L.T. Du Plessis (reds.). Afrikaans en taalpolitiek. Pretoria: HAUM. 17-36.

Bergh, J.S. en J.C. Visagie. 1985. The eastern cape frontier zone. 1660-1785. Durban: Butterworth. 
Boretzky, N., W. Enninger en T. Stolz (reds.). 1985. Akten des 1. Essener Kolloquiums über "Kreolsprachen und Sprachkontakte" vom 26.1.1985 an der Universität Essen. Bochum: Studienverlag Brockmeyer.

Boretzky, N., W. Enninger en T. Stolz (reds.). 1987a. Beiträge zum 3. Essener Kolloquium uber Sprachwandel und seine bestimmenden Faktoren. Bochum: Studienverlag Brockmeyer.

Boretzky, N., W. Enninger en T. Stolz (reds.). 1987b. Beiträge zum 4. Essener Kolloquium uber Sprachkontakt, Sprachwandel, Sprachwechsel, Sprachtod. Bochum: Studienverlag Brockmeyer.

Bosman, D.B. $1928^{2}$. Oor die ontstaan van Afrikaans. Amsterdam: Swets en Zeidinger.

Botha, T.J.R., F.A. Ponelis, J.G.H. Combrink, en F.F. Odendal (reds.). $1989^{2}$. Inleiding tot die Afrikaanse taalkunde. Pretoria: Academica.

Cairo, E. 1977. Ik ga dood om jullie hoofd. Haarlem: In de knipscheer.

Carstens, A. en H. Grebe (reds.). 2001. Taallandskap. Pretoria: Van Schaik.

Claassen, G.N. en M.C.J. van Rensburg (reds.). 1983. Taalverskeidenheid. 'n Blik op die spektrum van taalvariasie in Afrikaans. Pretoria, Kaapstad, Johannesburg: Academica.

De Ruyter, C. en E.F. Kotzé. 2002. Oor Austro-Nederlands en die oorsprong van Afrikaans. Literator 23 (3):139-160.

Den Besten, H. 1978. Cases of possible syntactic interference in the development of Afrikaans. Amsterdam Creole Studies 2:5-56.

Den Besten, H. 1985. Die doppelte Negation im Afrikaans und ihre Herkunft. In Boretzky, N., W. Enninger en T. Stolz (reds.). Akten des 1. Essener Kolloquiums über "Kreolsprachen und Sprachkontakte” vom 26.1.1985 an der Universität Essen. Bochum: Studienverlag Brockmeyer. 9-42.

Den Besten, H. 1986. Double Negation and the Genesis of Afrikaans. In Muysken, P. en N. Smith (reds.). Substrata versus Universals in Creole Genesis. Papers from the Amsterdam Creole Workshop, April 1985. Amsterdam/Phildelphia: Benjamins. 185-230.

Den Besten, H. 1987a. Die niederländischen Pidgins der alten Kapkolonie. In Boretzky, N., W. Enninger en T. Stolz (reds.). Beiträge zum 3. Essener Kolloquium uber Sprachwandel und seine bestimmenden Faktoren. Bochum: Studienverlag Brockmeyer. 9-40.

Den Besten, H. 1987b. Universal-Grammatik und/oder zweitsprachenerwerb: der Fall afrikaans. In Boretzky, N., W. Enninger en T. Stolz (reds.). Beiträge zum 4. Essener Kolloquium uber Sprachkontakt, Sprachwandel, Sprachwechsel, Sprachtod. Bochum: Studienverlag Brockmeyer. 11-44. 
Den Besten, H. 1989. From Khoekhoe foreignertalk via hottentot Dutch to Afrikaans: The creation of a novel grammar. In Pütz, M. en R. Dirven (reds.). Wheels within Wheels. Papers of the Duisburg Symposium on Pidgin and Creole Languages. Frankfurt: Peter Lang. 207-250.

Den Besten, H. 1994. 'Khoekhoe and its Speakers as a Key Factor in the Genesis of Afrikaans.' Bydrae tot die bundel kongresreferate The culture of multilinguality. UNISA, Departement Afrikatale, Pretoria, 3-5 Februarie 1994. Ongepubliseer.

Den Besten, H. 2001. The complex ancestry of the Afrikaans associative constructions. In Carstens, A. en H. Grebe (reds.). Taallandskap. Pretoria: Van Schaik. 49-58.

Du Plessis, H.G.W. 1994. Taalkontakvariasie in Afrikaans. In Olivier, G. en A. Coetzee (reds.). Nuwe Perspektiewe op die Geskiedenis van Afrikaans. Johannesburg: Southern Books. 120-129.

Du Plessis, H.G.W. 2011. Die pad na skuilhoek. Pretoria: LAPA.

Du Plessis, H.G.W. en L.T. Du Plessis. (reds.) 1987. Afrikaans en taalpolitiek. Pretoria: HAUM.

Elphick, R. en V.C. Malherbe. $1989^{2}$. The Khoisan to 1828. In Elphick, R. en H. Giliomee. (Reds.). The shaping of South African society, 1652 - 1840. Kaapstad: Maskew Miller Longman. 3-65.

Elphick, R. $1985^{2}$. Kraal and castle: Khoikhoi and the founding of white South Africa. Johannesburg: Ravan.

Elphick, R. en H. Giliomee (reds.). 1979. The shaping of South African society, 1652 - 1820. Kaapstad: Maskew Miller Longman.

Elphick, R. en H. Giliomee. (reds.). 1989². The shaping of South African society, 1652 - 1840. Kaapstad: Maskew Miller Longman.

Elphick, R. en H. Giliomee. $1989^{2}$. The origins and entrenchment of European dominance at the Cape, 1652-1840. In Elphick, R. en H. Giliomee. (reds.). The shaping of South African society, 1652 - 1840. Kaapstad: Maskew Miller Longman. 522-566.

Franken, J.L.M. 1953. Taalhistoriese bydraes. Kaapstad: Balkema.

Giliomee, H. 2009. The Afrikaners. Kaapstad: Tafelberg.

Giliomee, H. $1989^{2}$. The burgher rebellions on the Eastern Frontier, 1795-1815. In Elphick, R. en H. Giliomee. (reds.). The shaping of South African society, 1652 - 1840. Kaapstad: Maskew Miller Longman. 338-358. 
Guelke, L. $1989^{2}$. Freehold farmers and frontier settlers, 1657 - 1780. In Elphick, R. en H. Giliomee. (reds.). The shaping of South African society, 1652 - 1840. Kaapstad: Maskew Miller Longman. 66-101.

Hesseling, D.C. 1923. Het Afrikaans. Leiden: E.J. Brill.

Louw, S.A. 1948. Dialekvermenging en taalontwikkeling. Kaapstad: Balkema.

Mesthrie, R. (red.). 1995. Language and social history. Kaapstad: David Philip.

Muysken, P. en N. Smith (reds.). 1986. Substrata versus Universals in Creole Genesis. Papers from the Amsterdam Creole Workshop, April 1985. Amsterdam/Phildelphia: Benjamins.

Nienaber, G.S. 1934. Oor die Afrikaanse taal. Swets en Zeitlinger: Amsterdam.

Nienaber, G.S. 1942. Afrikaans tot 1860. Johannesburg: Voortrekkerpers.

Nienaber, G.S. 1963. Hottentots. Pretoria: Van Schaik.

Nienaber, G.S. 1964. Raakpunte met Hottentots. In Van der Merwe, H.J.J.M. (red.). Studierigtings in die taalkunde. Pretoria: Van Schaik. 192-207.

Nienaber, G.S. 1989. Khoekhoense stamname. 'n Voorlopige verkenning. Pretoria, Kaapstad: Academica.

Nienaber, G.S. 1994. Die ontstaan van Khoekhoe-Afrikaans. In Olivier, G. en A. Coetzee (reds.). Nuwe Perspektiewe op die Geskiedenis van Afrikaans. Johannesburg: Southern Books. 139-152.

Olivier, G. en A. Coetzee (reds.). 1994. Nuwe Perspektiewe op die Geskiedenis van Afrikaans. Johannesburg: Southern Books.

Ponelis, F.A. 1988. Afrikaans en taalversteuring. Tydskrif vir Geesteswetenskappe 28 (2):119149.

Ponelis, F.A. 1993. The Development of Afrikaans. Frankfurt am Main: Peter Lang.

Pütz, M. en R. Dirven (reds.). Wheels within Wheels. Papers of the Duisburg Symposium on Pidgin and Creole Languages. Frankfurt: Peter Lang.

Raidt, E. $1976^{2}$. Afrikaans en sy Europese Verlede. Kaapstad: Nasau.

Raidt, E. 1995. Women in the history of Afrikaans. In Mesthrie, R. (red.). Language and social history. Kaapstad: David Philip. 129-139. 
Raper, P.E., L. A. Möller en L. T. du Plessis. 2014. South African place names. Johannesburg and Cape Town: Jonathan Ball.

Schoeman, K. 2001. Armosyn van die Kaap. Die wêreld van 'n slavin, 1652 - 1733. Kaapstad: Human en Rousseau.

Scholtz, J. du P. 1963 Taalhistoriese Opstelle. Voorstudies tot 'n Geskiedenis van Afrikaans. Pretoria: Van Schaik.

Scholtz, J. du P. 1972. Afrikaans-Hollands in die agtiende eeu. Kaapstad: Nasou.

Scholtz, J. du P. 1980. Wording en ontwikkeling van Afrikaans. Kaapstad: Tafelberg.

Steyn, J.C. 1980. Tuiste in eie taal. Kaapstad: Tafelberg.

Traill, A. 1995. The Khoesan languages of South Africa. In Mesthrie, R. (red.). Language and social history. Kaapstad: David Philip. 1-18.

Van der Merwe, H.J.J.M. (red.). 1964. Studierigtings in die taalkunde. Pretoria: Van Schaik.

Van Oordt, J.F. 1949. Die Kaapse Taalargief 5-10. Tydskrif vir Wetenskap en Kuns 10-16 (10: 65-88. 11:55-75. 12:73-101. 13:45-73. 14:33-56. 16:97-124).

Van Oordt, J.F. 1947-1948. Die Kaapse Taalargief 1-4. Rondebosch: L.C. Van Oordt.

Van Rensburg, M.C.J. 1983. Nie-standaardvorme, variasiepatrone en Afrikaans van die vorige eeu. In Claassen, G.N. en M.C.J. van Rensburg (reds.). Taalverskeidenheid. 'n Blik op die spektrum van taalvariasie in Afrikaans. Pretoria, Kaapstad, Johannesburg: Academica. 134-161.

Van Rensburg, M.C.J. 1989. Soorte Afrikaans. In Botha, T.J.R. e.a. (reds.). 1989². Inleiding tot die Afrikaanse taalkunde. Pretoria: Academica. 436-467.

Van Rensburg, M.C.J. 1991. Finale verslag: Hedendaagse Oosgrensafrikaans. Ongepubliseerde RGN-verslag.

Van Rensburg, M.C.J. 1994. Die ontstaan van Afrikaans in 'n intertaalkonteks. In Olivier, G. en A. Coetzee (reds.). Nuwe Perspektiewe op die Geskiedenis van Afrikaans. Johannesburg: Southern Books. 166-170.

Van Rossem, C. en H. van der Voort (reds.). 1996. Die creool taal. Amsterdam: Amsterdam University Press.

Visagie, J. C. 2011. Voortrekkerstamouers 1835-1845. Pretoria: Protea Boekhuis. 